\title{
Report on earthquake-induced failures of rural buildings aimed at future preservation strategies
}

\author{
Marco Bovo, Alberto Barbaresi, Daniele Torreggiani, Patrizia Tassinari \\ Department of Agricultural and Food Sciences, University of Bologna, Italy
}

\begin{abstract}
The rural landscape is undergoing rapid changes, and catastrophic events, such as earthquakes, can speed up this mutation, bringing to a loss of its traditional signs. In May 2012, two strong seismic events hit the Emilia Romagna region, in northern Italy. Those earthquakes caused several damages and collapses to historical rural buildings, highlighting their high seismic vulnerability. In this paper, damages and collapses collected in the aftermath surveys on 22 rural historical buildings, are presented and commented. It was observed that in the area hit by the earthquake few recurrent typologies are present, and buildings of the same typology showed similar damage mechanisms. Therefore, in order to define the most typical damages affecting rural constructions, the building stock has been classified in different categories, based on plan distribution and intended use of each building. The first criterion suggests considering isolated and composed buildings. The second separates the structures in dwellings for residential use, stable-haylofts and buildings used for other minor services. The outcomes presented in this paper allowed to identify the rural building typologies most vulnerable to earthquakes and to define recurring deficiencies for the various categories. In general, the main reasons of the collapses can be ascribed to lack of effective connections between orthogonal walls, poor connections between floor elements and walls, and excessive flexibility of floor diaphragms.
\end{abstract}

Correspondence: Marco Bovo, Department of Agricultural and Food Sciences (DISTAL), University of Bologna, viale G. Fanin 48, 40127 Bologna, Italy.

E-mail: marco.bovo@unibo.it

Key words: Rural building; traditional technology; rural landscape; seismic damage; preservation strategy.

See online Appendix for additional figures.

Received for publication: 10 December 2018.

Accepted for publication: 19 March 2019.

(C) Copyright M. Bovo et al., 2019

Licensee PAGEPress, Italy

Journal of Agricultural Engineering 2019; L:930

doi:10.4081/jae.2019.930

This article is distributed under the terms of the Creative Commons Attribution Noncommercial License (by-nc 4.0) which permits any noncommercial use, distribution, and reproduction in any medium, provided the original author(s) and source are credited.

\section{Introduction}

Earthquakes can be terrible events since they can destroy constructions in entire regions, permanently modifying the landscape, producing severe environmental and economic impacts and even killing human lives. In fact, one of the most actual deal concerns estimating the social, environmental, and economic impacts of damage to buildings subject to seismic events (Hasik et al., 2018) and only starting from the analysis of damages suffered by buildings in past earthquakes is possible to calibrate tools (e.g. seismic loss estimation methods, economic input-output life cycle assessment) providing reliable assessments. In addition to other social and economic factors, earthquakes contribute to the transformation of rural landscape (Antrop, 2005): directly, producing damages and collapses, and indirectly, pushing to intense and rapid reconstructions with no specific attention to traditional rural building criteria.

As a worrisome warning, Figure 1 shows an example of the consequences of the seismic events in the landscape of a rural complex in the province of Modena (in the Northern Italy). After the serious seismic damages reported, the buildings have been demolished and replaced by a modern precast reinforced concrete structure, with no attention to the surrounding landscape and to traditional rural buildings. It is unnecessary to highlight that, even though it is possible to rebuild after a catastrophe, the effects of the earthquake can be permanently visible because of the relevant change left on the rural landscape.

In other words, the rural landscape is changing, and the preservation of its traditional features is a delicate matter; earthquakes and other catastrophic events can accelerate the transformation progress (Picuno, 2012). In order to avoid the loss of traditional landscape characterisation, two strategies are needed: the first one should aim at preserving the existing heritage; the second one should provide specific criteria for reconstruction when collapses are unavoidable. The latter strategy has been already addressed in some works, even integrating criteria for typology preservation with new criteria for energy efficiency and food safety (Barbaresi et al., 2017; Barreca et al., 2017) but no specific attention has been paid to building structural problems. The present paper aims at filling this gap, giving a contribution for the first strategy, identifying criticalities of traditional rural buildings due to seismic events.

In May 2012, more than 1000 seismic events with magnitude bigger than 2.0 (http://www.iesn.it) hit the Emilia Romagna Region, in Northern Italy. Two strong earthquakes with very close epicentres (distance of about $11 \mathrm{~km}$ ) characterised the sequence. The first main shock of May $20^{\text {th }}$ (epicentre latitude and longitude respectively $44.89 \mathrm{~N}$ and $11.23 \mathrm{E}$ ) had local magnitude equal to 5.9 and peak ground acceleration (PGA) of $258.80 \mathrm{~cm} / \mathrm{s}^{2}$ (i.e. 0.26 g). For the second main shock of May $29^{\text {th }}$ (epicentre latitude and longitude respectively $44.85 \mathrm{~N}$ and $11.09 \mathrm{E}$ ) a local magnitude of 
5.8 was calculated and a $\mathrm{PGA}=411.37 \mathrm{~cm} / \mathrm{s}^{2}$ (i.e. $0.42 \mathrm{~g}$ ) was recorded (http://itaca.mi.ingv.it). Appendix Figure 1A and B show the position of epicentres and the shake maps for the two closerange earthquakes. Instead, Table 1 reports some interesting information collected during the two main shocks of 2012 by accelerometric registration stations close to epicentres. Then, Appendix
Figure $1 \mathrm{C}$ and D compares the elastic acceleration response spectra recorded during the two main events and the elastic spectra prescribed by national code (ANTC, 2018), for the municipality of Mirandola, for the life safety limit states design of a new residential building (i.e. dwelling) and a new rural warehouse. As showed by the comparison, the accelerations produced by the earthquakes

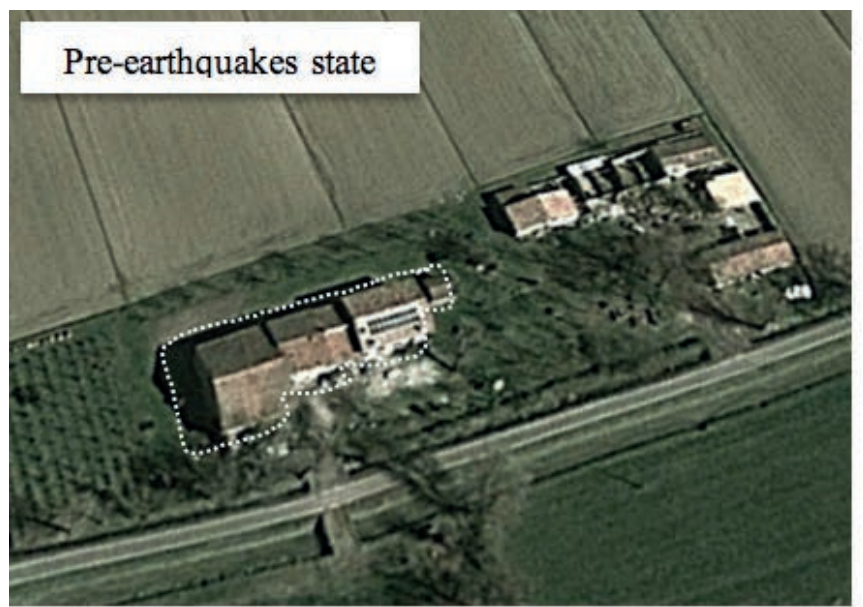

A

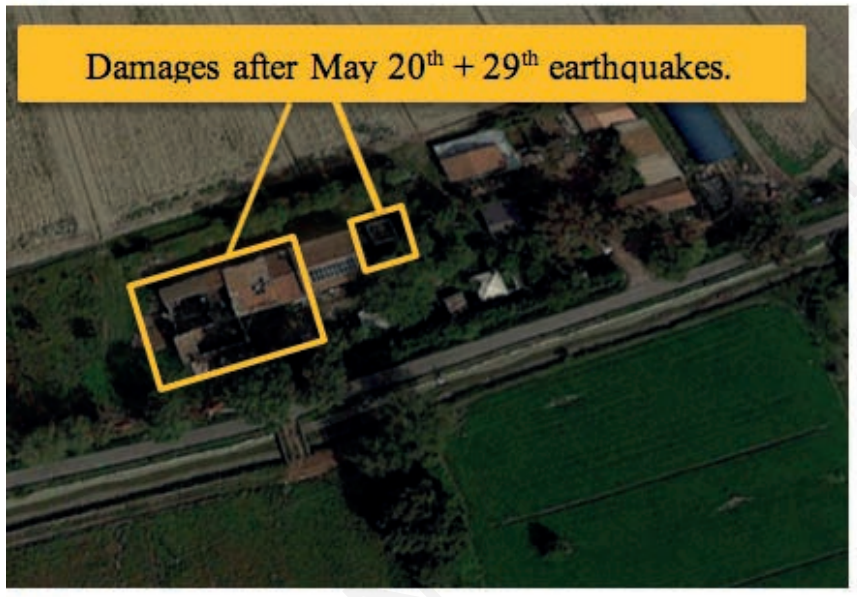

C

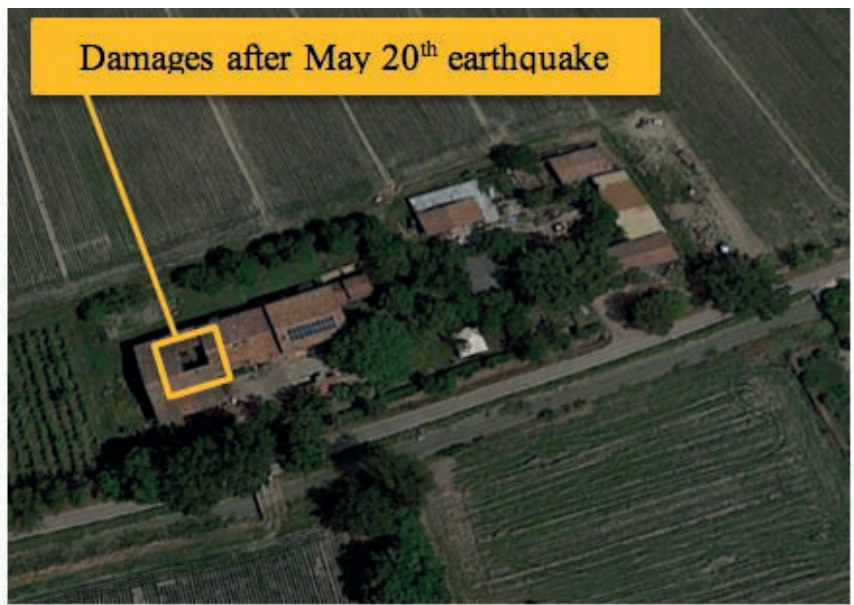

B

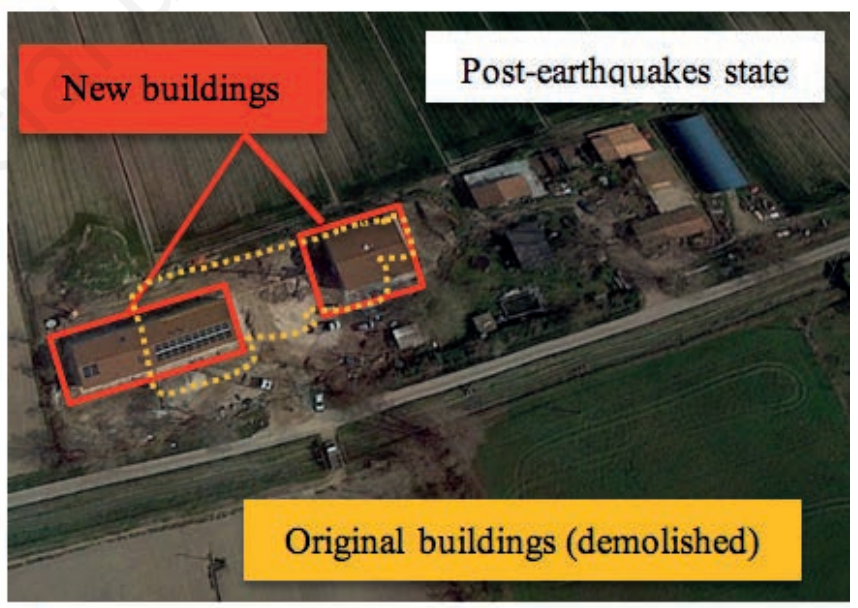

D

Figure 1. Aerial view of a rural complex in: A) 2008; B) few days after 2012 May, $20^{\text {th }}$ earthquake; C) few days after 2012 May, $29^{\text {th }}$ earthquake; and D) currently (2018) showing the demolition of the damaged structures and the construction of new modern buildings. The effects of the earthquake are permanently visible because of the relevant change left on the rural landscape.

Table 1. Main information recorded by accelerometric stations close to epicentres during the two main shocks of 2012.

\begin{tabular}{|c|c|c|c|c|c|c|c|}
\hline \multirow[t]{2}{*}{ Station code } & \multirow{2}{*}{ Station name } & \multirow[t]{2}{*}{ Lat. $\left[{ }^{\circ}\right]$} & \multirow[t]{2}{*}{ Long. $\left[{ }^{\circ}\right]$} & \multicolumn{2}{|c|}{ May $20^{\text {th }}$} & \multicolumn{2}{|c|}{ May 29th } \\
\hline & & & & $\mathrm{D}[\mathrm{km}]$ & $\mathrm{PGA}\left[\mathrm{cm} / \mathrm{s}^{2}\right]$ & $\mathrm{D}[\mathrm{km}]$ & PGA $\left[\mathrm{cm} / \mathrm{s}^{2}\right.$ \\
\hline MIR01 & Medolla & 44.84 & 11.07 & - & - & 0.5 & 411.37 \\
\hline MRN & Mirandola & 44.87 & 11.06 & 16.1 & 297.3 & 4.1 & 840.74 \\
\hline MOG0 & Moglia & 44.93 & 10.91 & - & - & 15.8 & 235.62 \\
\hline FIN0 & Finale Emilia & 44.82 & 11.28 & - & - & 17.5 & 234.28 \\
\hline MODE & Modena & 44.62 & 10.94 & 38.6 & 41.85 & 25.3 & 44.09 \\
\hline MDN & Modena 1 & 44.64 & 10.88 & 40.5 & 36.24 & 25.7 & 50.53 \\
\hline$\underline{\mathrm{ZPP}}$ & Zola Predosa Piana & 44.52 & 11.20 & 41.5 & 22.81 & 36.9 & 22.3 \\
\hline
\end{tabular}

D, distance from epicentre; PGA, peak ground acceleration. 
are remarkably bigger than the expected and currently adopted for the design of new buildings in the area. It is worth to note that the maximum PGA recorded for the second event (i.e. $0.42 \mathrm{~g}$ ) is comparable to the currently expected one, following the actual Italian seismic hazard map (http://shakemap.rm.ingv.it/shake/index.html), for an event with about 1000 years return period. Nevertheless, the main reason of the collapse of most of the rural buildings has to be attributed to an incorrect design philosophy (Özmen and Ünay, 2007), typical of past construction techniques of non-seismic zones, which considered only gravitational and wind loads. In fact, the Emilia area in the Emilia-Romagna Region was considered as non-seismic zone by Italian regulations until 2003, therefore most of the buildings hit by the earthquake were designed without seismic rules. Moreover, old rural buildings typically represent low quality constructions built with poor construction techniques and materials. The territories stricken by the earthquakes are moderately populated (varying from 50 to 300 inhabitants per square kilometre) and characterised by small residential zones and medium industrial area surrounded by rural landscape. Some of the most important Italian food farming brands have their headquarters in this area, making the region one of the most densely industrialised in the northern part of the country. Several collapses and extended damages occurred to precast reinforced concrete industrial structures (Belleri et al., 2014; Bovo and Savoia, 2018), masonry monumental heritage (Cattari et al., 2013; Parisi and Augenti, 2013; Penna et al., 2013) and historical rural buildings (Sorrentino et al., 2014), highlighting that vernacular buildings represent one of the most vulnerable categories in a geographical region where the agricultural activities play a fundamental role for the economy of the territory.

The first earthquake damaged heavily the districts of San Carlo di Sant'Agostino, Mirabello, Finale Emilia and San Felice sul Panaro (Modena and Ferrara Provinces, Emilia-Romagna region). The second main shock caused collapses in the areas of Mirandola, Medolla, Cavezzo, Novi di Modena and Moglia (Modena and Ferrara Provinces, Emilia-Romagna region). In the aftermath of the earthquakes, close to the epicentres, spread soil liquefaction phenomena have been observed. By processing the outcomes of the building surveys activated immediately after the sequence, about $25 \%$ of the residential buildings and $45 \%$ of the industrial facilities turned out to be unsafe and were tagged as condemned because they reported significant damages or failures (http://www.regione.emilia-romagna.it/terremoto).

As far as historical vernacular buildings in the area hit by the earthquakes are concerned, it was observed that few recurrent typologies are present. Moreover, same typology of buildings, typically, showed similar damage mechanisms. Therefore, even if every structure has its own peculiarities, it is possible to subdivide the rural building stock of the Emilia area in few categories and then connect each category with some recurrent seismic damage mechanisms. This allows identifying the building typologies most vulnerable to earthquakes, and, from the lesson learned after recent seismic events, to plan the future most effective planning strategies in order to increase the safety of historical rural constructions. The rural buildings are nowadays a huge cultural heritage since they represent the architectural, environmental and social distinguishing features of the Emilia Romagna landscape and history. On the contrary, despite their importance, specific laws or regulations for their preservation are nowadays not in effect and, in several cases, these buildings are currently abandoned and in advanced deterioration state. More in detail, in this paper, a simple classification criterion is provided for the building stock, and for each category, the main collapse mechanisms highlighted by the seismic sequence are reported and discussed. Then, the main causes of the failures are investigated and commented in order to provide a better understanding of the dynamic behaviour for these vulnerable buildings. The knowledge of the existing deficiencies represent a necessary information to propose future proper repair and conservation interventions (Toker and Ünay, 2006). The definition of the strengthening interventions will be object of future study and is not discussed in the present paper. Some preliminary details on seismic performance of traditional buildings and technical solutions for their strengthening can be found in several studies (Giuriani and Marini, 2008; Piazza et al., 2008; Gattesco and Macorini, 2014; Scotta et al., 2018).

\section{Materials and methods}

First, documentation about 22 vernacular buildings hit by the 2012 Emilia Romagna earthquakes has been collected by on field surveys. Then, the damages have been studied and classified; under this light, the methodology of this paper can be considered as a lesson learned experience, since the effects of the earthquakes have been studied to reduce or eliminate the potential for failures and mishaps or reinforces a positive result (Secchi, 1999).

The paper, after the description of the seismic events, identifies representative rural buildings that suffered severe consequences during the Emilia earthquakes, groups them according to plan distribution and intended use, then classifies the damages and collapses, and finally gathers damages and collapses based on the building categories.

Currently, according to the 2011 census of the Italian National Institute for Statistics (www.istat.it), in the municipalities of the area hit by the earthquakes, most of the structures are masonry buildings with two storeys on average. The rural buildings represent a relevant percentage of the whole stock. The Emilia Romagna region is a quite extended region, covering a surface of about $22,450 \mathrm{~km}^{2}$, and obviously, socio-economic conditions, territorial vocation, local construction technologies and materials, and historical events strong influenced the growth of the settlements constituting the present building heritage. Despite to this, the Po valley area stricken by earthquakes has similar vocation (mainly because of the local geography) and most of the historical rural buildings have been built in a narrow period of about 150 years (i.e. XIX century and half of XX century). In fact, most of rural dwellings built before the XIX century were built with natural perishable materials (e.g. mud, straws, wood, canes and raw bricks), and after World War II the changes in socio-economic conditions soon imposed new building typologies. The consequence is that, albeit every structure has its own geometries, dimensions, architectural arrangement and distribution of inner space, the historical vernacular building heritage of the area is quite homogeneous and can be subdivided in few typological categories. Based on ancient historical research in the area, Ortolani (1953) describes the typical rural courtyard as depicted in Appendix Figure 2A. The main buildings of a settlement in the area of Modena are the house with basic rooms (with at ground floor kitchen, warehouse, and basement; at the first-floor bedrooms and a little granary), the stable-hayloft and some buildings for minor services (toilet shack, garage, roost etc.). Often the house and the stable-hayloft were built one adherent to the other. In other cases, maybe more typical of the areas surrounding Reggio Emilia, two buildings are connected by a transition element, the porta morta (i.e. blind door) volume. This element is depicted in the particulars of Appendix 
Figure 2B. The porta morta represented a protected passage where the peasants undressed before entering the house, and sometimes was used to collect and dry spices and small amounts of cereals. The volume was typically open, with a masonry arch on the front side, and closed by walls on the back, and this gives the name. In more modern buildings, the porta morta was opened on both façades, and the backside closed by a removable wooden door. Two main typologies of rural dwellings exist: larger ones, with several families inhabiting the house (i.e. patriarchal home); smaller ones, where only one family used to live (i.e. mono-nucleus home). Alberti, in the XV century (Alberti, 1450), provided a detailed description of the functional organisation of the peasant house that reflects in a very representative way the buildings currently present in the Emilia area. Typically, the greatest farms had other types of buildings, in order to store more hay or protect tools. The most widespread types are the barchessa and the casella, that are isolated rectangular buildings, 4-6 meters high, with 6-10 m and $15-20 \mathrm{~m}$ plan dimensions, respectively for the transverse and the longitudinal direction. The barchessa was vertically closed on three façades, instead the casella just on one or two. For the classification and subdivision of the building stock of the present

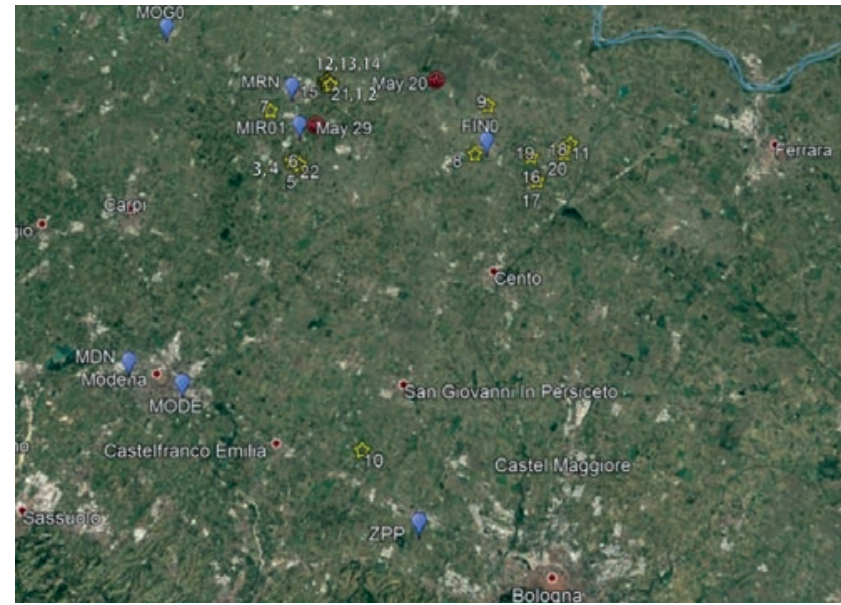

Figure 2. Area stricken by the Emilia earthquakes reporting the position of epicentres of May $20^{\text {th }}$ and May $2^{\text {th }}$ ground motions (red circles), the location of buildings constituting the stock of the present paper (yellow stars) and accelerometric registration stations (blue markers) with the codes reported in Table 2.

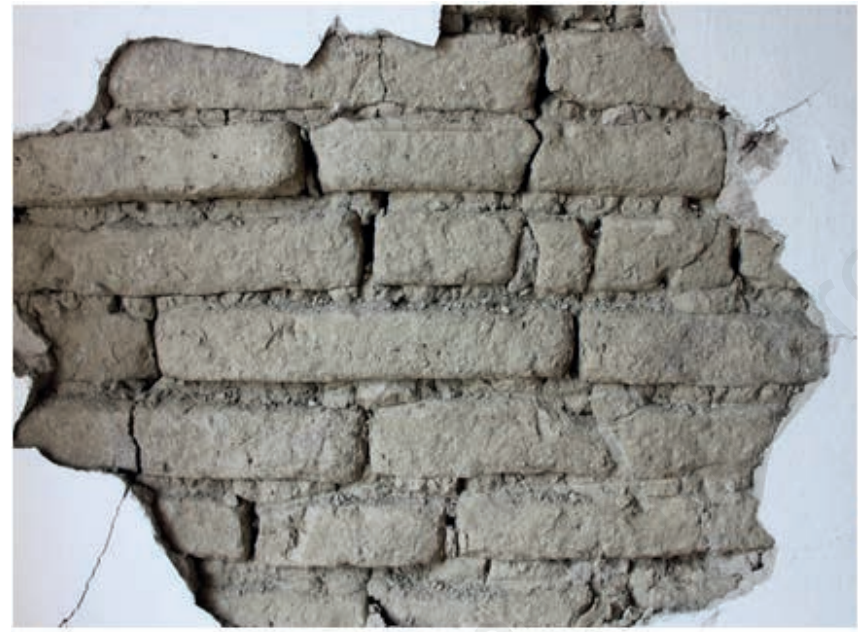

$\mathbf{A}$

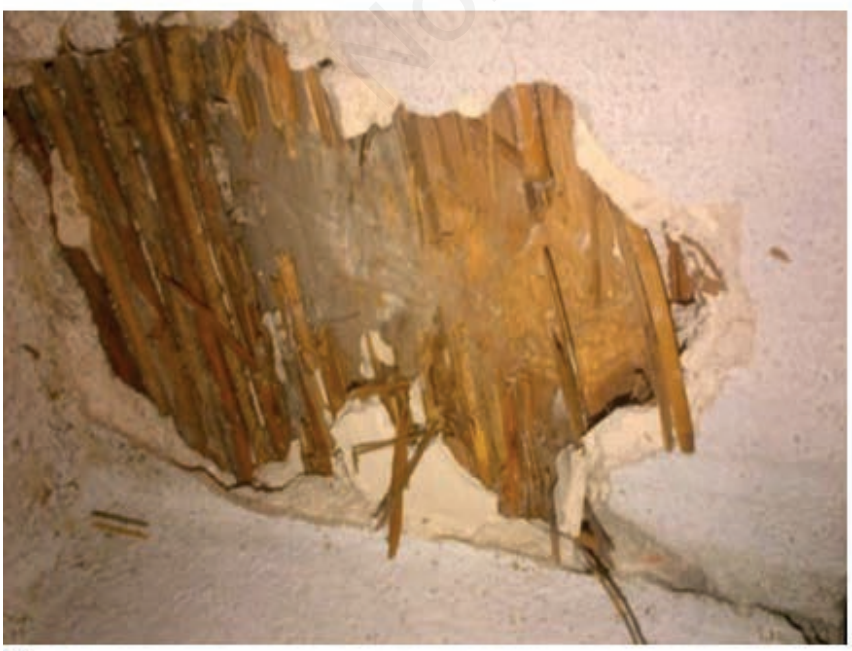

C

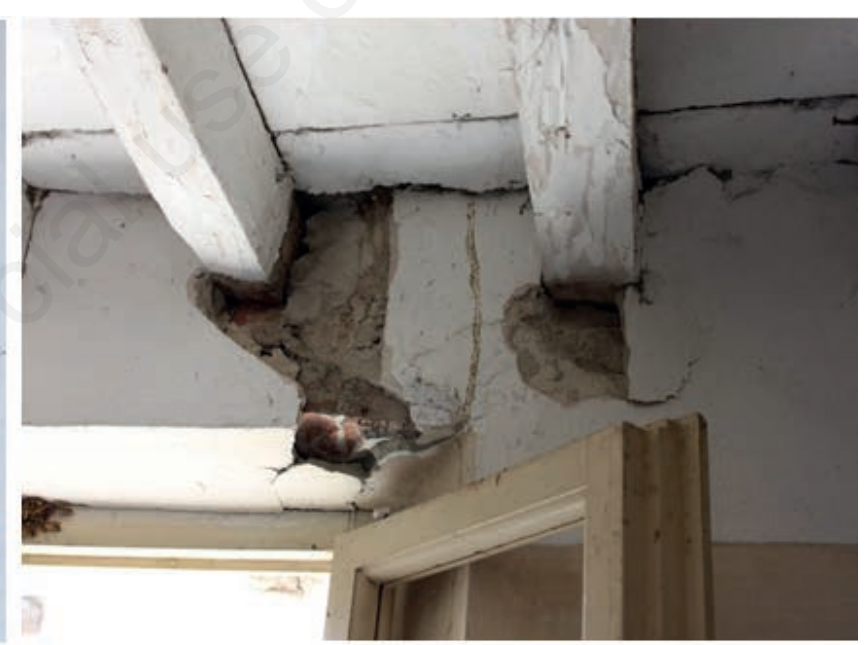

B

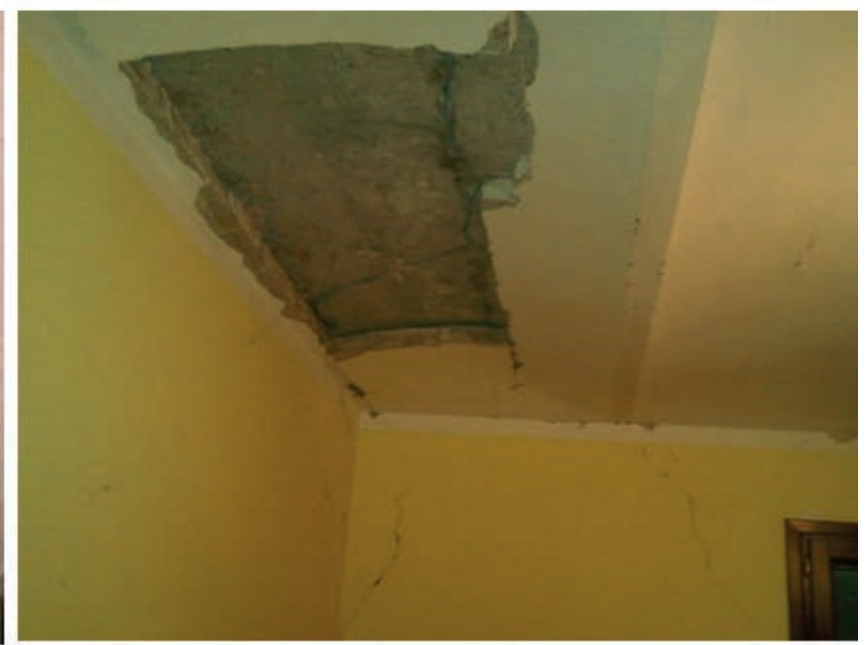

D

Figure 3. Particulars on materials and construction techniques of historical rural buildings. A) Masonry wall texture. B) Structure of a wooden floor; C) Cane panels protecting timber beams. D) Vaulted masonry floor. 
study, two very simple criteria have been adopted. This is justified by the reason that for some buildings, poor and often partial information were available, especially for those collapsed. The unavailability of in-field data has been, in few cases, covered by information extracted by the original projects of the structures. With the data at hand, the two criteria have been selected in order to search for a compromise between simplicity, homogeneity of the buildings in a category, and statistics representativeness of the samples.

The first criterion refers to geometry and plan distribution of the building, while the second to the building use. This choice is justified by the in-field evidence that buildings with similar use have analogous geometrical dimensions, materials and construction techniques guaranteeing sufficient homogeneity of the samples in a category. Following the first criterion, buildings are considered isolated (structurally not connected to other bodies) (A) or composed (made up of several structurally connected bodies) (B). According to the second criterion, the following types are identified: i) dwelling for residential use; ii) stable-hayloft; iii) barches$s a$ or casella; iv) building used for other minor services.

In the following section, we will describe the most spread damage and failure mechanisms observed, for each building category, in aftermath building surveys on a stock of 22 damaged rural structures. As far as the category A3 is concerned, the authors had information on two buildings only. Due to the reduced samples number in the category A3, the damage mechanisms could be not completely representative of the category. Anyway, the buildings of category A3 are very particular and specific of the Provinces hit by the earthquakes, and for this reason the authors decided to maintain the category $\mathrm{A} 3$ in the study.

\section{Results and discussion}

The geographical position of the buildings, of earthquake epicentres, and some accelerometric stations are reported in Figure 2. The main characteristics of the building stock considered here are summarised in Tables 2 and 3, while Table 4 reports damages and collapses detected for each building category.

\section{Damages to building category A1}

As far as A1 group (isolated dwellings) is concerned, the typical building (abbreviated bldg. in the figure captions) has $25-30 \mathrm{~cm}$ thick masonry walls, made up with irregular raw bricks and poor hydraulic mortar brickworks (Figure 3A), with 2.50-2.80 m net floor height and no more than three floors. The inter-storey floors are built with timber beams (Figure 3B) poorly connected to perimeter walls and pavement constituted by single layer wood plank resulting extremely flexible and unsuitable to transfer seismic actions. Sometimes, cane panels supporting a thin layer of plaster cover the beams (Figure 3C). In other cases, there are steel floor beams with masonry vaults as showed in Figure 3D. As well-known from literature (e.g. Tomazevic, 2000), typical damage mechanisms affecting vertical elements of unreinforced masonry buildings can be classified in mode I failure mechanisms (or local mechanisms) and mode II failure mechanisms (or global mechanisms). The mode I failure mechanisms consist in out-of-plane wall failure (e.g. out-of-plane overturning, horizontal and vertical out-of-plane flexure), instead the mode I mechanisms involve the reaching of strength capacity in the wall plane (e.g. inplane flexure and in-plane shear failure mechanism). The typical damages observed for this class of buildings are consequences of

Table 2. General information on the building stock.

\begin{tabular}{|c|c|c|c|c|}
\hline Bldg. \# & Building category & Latitude & Longitude & Notes on intended use \\
\hline 1 & $\mathrm{~A} 2$ & 44.892 & 11.102 & Stable-hayloft \\
\hline 2 & $\mathrm{Al}$ & 44.895 & 11.101 & Residential dwelling \\
\hline 3 & $\mathrm{Al}$ & 44.824 & 11.064 & Residential dwelling \\
\hline 4 & A2 & 44.825 & 11.063 & Stable-hayloft \\
\hline 5 & B1-2 & 44.823 & 11.069 & House adjacent to stable-hayloft \\
\hline 6 & $\mathrm{Al}$ & 44.821 & 11.072 & Residential dwelling \\
\hline 7 & B1-2 & 44.869 & 11.037 & House adjacent to stable-hayloft \\
\hline 8 & B1-2 & 44.831 & 11.273 & House adjacent to stable-hayloft \\
\hline 9 & A4 & 44.873 & 11.289 & Warehouse \\
\hline 10 & $\mathrm{~A} 2$ & 44.589 & 11.144 & Stable-hayloft \\
\hline 11 & A3 & 44.839 & 11.383 & Originally casella than infilled on transverse sides \\
\hline 12 & B1-2 & 44.896 & 11.102 & House adjacent to stable-hayloft \\
\hline 13 & A4 & 44.895 & 11.102 & Pigsty \\
\hline 14 & A4 & 44.896 & 11.102 & Warehouse \\
\hline 15 & $\mathrm{Al}$ & 44.892 & 11.107 & Residential dwelling \\
\hline 16 & B1-4 & 44.807 & 11.344 & House between warehouse and vernacular chapel \\
\hline 17 & A4 & 44.807 & 11.343 & Warehouse \\
\hline 18 & $\mathrm{~A} 2$ & 44.831 & 11.376 & Stable-hayloft \\
\hline 19 & $\mathrm{Al}$ & 44.828 & 11.338 & Residential dwelling \\
\hline 20 & $\mathrm{Al}$ & 44.834 & 11.376 & Residential dwelling \\
\hline 21 & A4 & 44.892 & 11.107 & Warehouse-garage \\
\hline 22 & A3 & 44.821 & 11.072 & Barchessa \\
\hline
\end{tabular}


mode II failure mechanisms (i.e. flexure or shear mechanism in the plane of the wall) to perimeter and partition walls as depicted in Figure 4A and B. Due to limited in-plane dimensions compared to thickness, the mode I failure mechanisms usually did not appear, even if the connections between orthogonal walls are very poor, as showed in Figure 4C.
Moreover, the floor-wall connection is rather lacking: in many cases, the sliding of the beams from the masonry (Figure 3B) or even the failure was observed, due to loss of support, as documented in Figure 4D. In few cases, also failure of lintels (Figure 4E) or masonry arches (Figure 4F) typically involving permanent settlements to the horizontal structures of the floors occurred.

Table 3. Main geometrical/materials information on the building stock collected during the surveys.

\begin{tabular}{|c|c|c|c|c|c|c|}
\hline Bldg. \# & $\begin{array}{c}\text { Plan } \\
\text { dimensions (m) }\end{array}$ & $\begin{array}{l}\text { Number of } \\
\text { floors }\end{array}$ & $\begin{array}{l}\text { Max height } \\
\text { (m) }\end{array}$ & $\begin{array}{l}\text { Floors materials- } \\
\text { techniques }\end{array}$ & $\begin{array}{l}\text { Roof materials- } \\
\text { techniques }\end{array}$ & $\begin{array}{l}\text { Walls materials- } \\
\text { techniques }\end{array}$ \\
\hline 1 & $20.7 \times 17.0$ & 2 & 11.1 & $\begin{array}{l}\text { Steel beams with vaulted } \\
\text { holed bricks }\end{array}$ & $\begin{array}{l}\text { Main+secondary } \\
\text { timber beams }\end{array}$ & Fired bricks $\mathrm{t}=30 \mathrm{~cm}$ \\
\hline 2 & $18.5 \times 11.4$ & 3 & 10.3 & Timber beams & $\begin{array}{l}\text { Main+secondary } \\
\text { timber beams }\end{array}$ & Fired bricks $\mathrm{t}=30 \mathrm{~cm}$ \\
\hline 3 & $15.2 \times 11.2$ & 3 & 7.90 & Timber beams & $\begin{array}{l}\text { Main+secondary } \\
\text { timber beams }\end{array}$ & Fired bricks $\mathrm{t}=30 \mathrm{~cm}$ \\
\hline 4 & $19.9 \times 16.6$ & 2 & 9.70 & $\begin{array}{l}\text { Steel beams with } \\
\text { vaulted holed bricks }\end{array}$ & $\begin{array}{l}\text { Main }+ \text { secondary timber } \\
\text { beams }\end{array}$ & Raw bricks $\mathrm{t}=30 \mathrm{~cm}$ \\
\hline 5 & $13.5 \times 29.7$ & $2 / 3$ & $10.70 / 11.50$ & $\begin{array}{l}\text { Main+secondary timber } \\
\text { beamsNaulted floor with RC slab }\end{array}$ & $\begin{array}{l}\text { Main+secondary } \\
\text { timber beams }\end{array}$ & Fired bricks $t=30 \mathrm{~cm}$ \\
\hline 6 & $9.10 \times 19.0$ & 3 & 9.70 & $\mathrm{RC}$ beams with holed bricks & $\begin{array}{l}\text { Main+secondary } \\
\text { timber beams }\end{array}$ & Fired bricks $t=30 \mathrm{~cm}$ \\
\hline 7 & $35.3 \times 9.10$ & $3 / 2$ & $8.30 / 8.20$ & $\begin{array}{l}\text { RC beams with holed bricks/ } \\
\text { Steel beams with vaulted holed bricks }\end{array}$ & $\begin{array}{l}\text { Main+secondary } \\
\text { timber beams }\end{array}$ & $\begin{array}{l}\text { Fired bricks } t=35 \mathrm{~cm} / \\
\text { Fired bricks } t=30 \mathrm{~cm}\end{array}$ \\
\hline 8 & $21.43 \times 18.27$ & $2 / 2$ & $8.30 / 9.75$ & RC beams with holed bricks & $\begin{array}{l}\text { Main+secondary } \\
\text { timber beams }\end{array}$ & Raw bricks $\mathrm{t}=30 \mathrm{~cm}$ \\
\hline 9 & $6.50 \times 17.6$ & 2 & 8.90 & RC beams with holed bricks & $\begin{array}{l}\mathrm{RC} \text { beams with } \\
\text { holed bricks }\end{array}$ & Raw bricks $\mathrm{t}=30 \mathrm{~cm}$ \\
\hline 10 & $16.6 \times 14.0$ & 2 & 9.30 & RC slab & $\begin{array}{l}\text { Main+secondary } \\
\text { timber beams }\end{array}$ & Fired bricks $t=30 \mathrm{~cm}$ \\
\hline 11 & $8.70 \times 5.30$ & 1 & 6.40 & 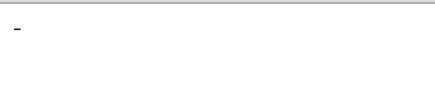 & $\begin{array}{l}\text { Main+secondary } \\
\text { timber beams }\end{array}$ & Fired bricks $t=25 \mathrm{~cm}$ \\
\hline 12 & $12.2 \times 21.0$ & $2 / 2$ & $10.4 / 10.9$ & $\begin{array}{l}\text { RC beams with holed bricks/ } \\
\text { Steel beams with vaulted holed bricks }\end{array}$ & $\begin{array}{l}\text { Main+secondary } \\
\text { timber beams }\end{array}$ & $\begin{array}{l}\text { Fired bricks } t=30 \mathrm{~cm} / \\
\text { Fired bricks } t=30 \mathrm{~m}\end{array}$ \\
\hline 13 & $6.15 \times 8.05$ & 1 & 3.80 & - & Timber beams & Fired bricks $\mathrm{t}=25 \mathrm{~m}$ \\
\hline 14 & $14.0 \times 6.90$ & 2 & 7.25 & $\mathrm{RC}$ beams with holed bricks & $\begin{array}{l}\text { Main }+ \text { secondary } \\
\text { timber beams }\end{array}$ & Fired bricks $\mathrm{t}=15 \mathrm{~m}$ \\
\hline 15 & $25.0 \times 10.8$ & 3 & 8.20 & Main+secondary timber beams & $\begin{array}{l}\text { Main+secondary } \\
\text { timber beams }\end{array}$ & Fired bricks $\mathrm{t}=30 \mathrm{~m}$ \\
\hline 16 & $14.6 \times 8.60$ & 2 & 7.90 & RC beams with holed bricks & $\begin{array}{l}\text { Main+secondary } \\
\text { timber beams }\end{array}$ & Fired bricks $\mathrm{t}=30 \mathrm{~m}$ \\
\hline 17 & $12.9 \times 3.40$ & 2 & 5.10 & Timber beams & $\begin{array}{l}\text { Main+secondary } \\
\text { timber beams }\end{array}$ & Raw bricks $\mathrm{t}=25 \mathrm{~cm}$ \\
\hline 18 & $15.3 \times 13.5$ & 2 & 8.20 & Steel beams with vaulted holed bricks & $\begin{array}{l}\text { Main+secondary } \\
\text { timber beams }\end{array}$ & Fired bricks $t=25 \mathrm{~cm}$ \\
\hline 19 & $13.7 \times 12.3$ & 2 & 8.00 & Main+secondary timber beams & $\begin{array}{l}\text { Main+secondary } \\
\text { timber beams }\end{array}$ & Fired bricks $\mathrm{t}=30 \mathrm{~m}$ \\
\hline 20 & $15.5 \times 5.40$ & 3 & 7.90 & RC beams with holed bricks & $\begin{array}{l}\text { Main+secondary } \\
\text { timber beams }\end{array}$ & Fired bricks $\mathrm{t}=30 \mathrm{~m}$ \\
\hline 21 & $19.6 \times 13.3$ & 2 & 7.30 & Timber beams & $\begin{array}{l}\text { Main+secondary } \\
\text { timber beams }\end{array}$ & Fired bricks $t=30 \mathrm{~m}$ \\
\hline 22 & $8.20 \times 5.15$ & 1 & 6.60 & - & $\begin{array}{l}\text { Main+secondary } \\
\text { timber beams }\end{array}$ & Fired bricks $\mathrm{t}=25 \mathrm{~m}$ \\
\hline
\end{tabular}

$\mathrm{RC}$, reinforced concrete. 


\section{Damages to building category A2}

Most of the seismic damages in the region affected the category A2 of the stable-hayloft buildings. In fact, into this category, several collapses or permanent damages, and consequent building demolitions, have been reported. The structure physiognomy of stable-haylofts makes this specific group of buildings extremely vulnerable to seismic actions. The most widespread typology of isolated historical stable-hayloft has the geometry exhibited in Appendix Figure $3 \mathrm{~A}$ and $\mathrm{B}$. The need to achieve great volumes to store hay and wheat without introducing inner structure elements brought the adoption of long and high, usually very slender, single leaf masonry walls. In other cases, masonry columns infilled by single course $(12-15 \mathrm{~cm}$ thick) walls were realised. The interstorey floor over the stable typically has masonry vaults surrounded by internal columns as in Appendix Figure 3C. Instead, the roof has wooden trussed structure with two or four pitches. In several cases, in the facade, the building has a portico adopted in past to store grain or shelter the work tools (Appendix Figure 3D).

Table 4. Summary of the main damages and collapses observed for the various categories.

\begin{tabular}{|c|c|c|c|}
\hline Building category & Damages/Collapses mechanisms & Building \# & Deficiencies \\
\hline \multicolumn{4}{|l|}{ A (isolated buildings) } \\
\hline Al (dwelling) & $\begin{array}{l}\text { DAMAGES } \\
\text { - Cracks for in-plane wall flexure } \\
\text { - X cracks for in-plane wall shear } \\
\text { - Wall-wall corner cracks } \\
\text { - Cracks on partition walls } \\
\text { - Floor beams sliding } \\
\text { COLLAPSES } \\
\text { - Floor beams fall down } \\
\text { - Lintels/arches }\end{array}$ & $\begin{array}{l}3,6,20 \\
2,15,19,20 \\
2,3,6 \\
2,3,6,15 \\
2,3,6,19 \\
2 \\
20,3\end{array}$ & $\begin{array}{l}\text { - Flexible interstorey diaphragm } \\
\text { - Flexible roof } \\
\text { - Lacking floor-wall connections } \\
\text { - Lacking wall-wall connections } \\
\text { - poor materials strength }\end{array}$ \\
\hline A2 (stable-hayloft) & $\begin{array}{l}\text { DAMAGES } \\
\text { - Floor beams sliding } \\
\text { - Wall cracks } \\
\text { COLLAPSES } \\
\text { - Wall overturning l. m. } \\
\text { - Out-of-plane wall flexure l. m. } \\
\text { - Flexure-shear columns failure } \\
\text { - Roof beams fall down }\end{array}$ & $\begin{array}{l}1,4,10 \\
1,4,18 \\
1 \\
10,18 \\
1,4 \\
1,4,18\end{array}$ & $\begin{array}{l}\text { - Flexible roof } \\
\text { - Slender walls } \\
\text { - Distance between vertical walls } \\
\text { - Lacking roof-wall connections } \\
\text { - Lacking wall-wall connections } \\
\text { - In-plane asymmetry } \\
\text { - Non-regular infills } \\
\text { - In-elevation irregularity }\end{array}$ \\
\hline A3 (barchessa and casella) & $\begin{array}{l}\text { DAMAGES } \\
\text { - Permanent settings } \\
\text { - Cracks on column-infills connections } \\
\text { COLLAPSES: } \\
\text { - Out-of-plane wall flexure l. m. } \\
\text { - Roof beams fall down }\end{array}$ & $\begin{array}{l}11 \\
11 \\
22 \\
22\end{array}$ & $\begin{array}{l}\text { - Flexible roof } \\
\text { - Slender walls/columns } \\
\text { - Lacking roof-wall connections } \\
\text { - In-plane asymmetry } \\
\text { - Non-regular infills }\end{array}$ \\
\hline A4 (minor services building) & $\begin{array}{l}\text { DAMAGES } \\
\text { - Cracks for in-plane wall flexure } \\
\text { - X cracks for in-plane wall shear } \\
\text { - Cracks on infills/partitions } \\
\text { COLLAPSES } \\
\text { - Roof beams fall down } \\
\text { - Overturning of infills }\end{array}$ & $\begin{array}{l}9,13 \\
13,14 \\
13,14,17 \\
9,13 \\
9,17\end{array}$ & $\begin{array}{l}\text { - Flexible roof } \\
\text { - Lacking roof-wall connections } \\
\text { - Non-regular infills } \\
\text { - Poor materials strength }\end{array}$ \\
\hline \multicolumn{4}{|l|}{ B (composed buildings) } \\
\hline B1-2 (dwelling- stable-hayloft) & $\begin{array}{l}\text { DAMAGES } \\
\text { - X cracks for in-plane wall shear } \\
\text { - Wall-wall corner cracks } \\
\text { - Cracks on partition walls } \\
\text { - Floor beams sliding } \\
\text { - Base column cracks } \\
\text { COLLAPSES } \\
\text { - Floor/roof beams fall down } \\
\text { - Infills failure } \\
\text { - Cornice fall down }\end{array}$ & $\begin{array}{l}8,12 \\
5,8,12 \\
7,8,12 \\
8,12 \\
7 \\
\\
5,8 \\
5 \\
5\end{array}$ & $\begin{array}{l}\text { - Same as for } \mathrm{A} 1 \text { and } \mathrm{A} 2 \\
\text { - Interaction between adjacent bodies }\end{array}$ \\
\hline B1-4 (dwelling-minor services) & $\begin{array}{l}\text { DAMAGES } \\
\text { - Wall-wall corner cracks } \\
\text { - Cracks on partition walls } \\
\text { COLLAPSES } \\
\text { (Not observed) }\end{array}$ & $\begin{array}{l}16 \\
16\end{array}$ & $\begin{array}{l}\text { - Same as for Al } \\
\text { - Interaction between adjacent bodies }\end{array}$ \\
\hline
\end{tabular}

l. m., local mechanism. 

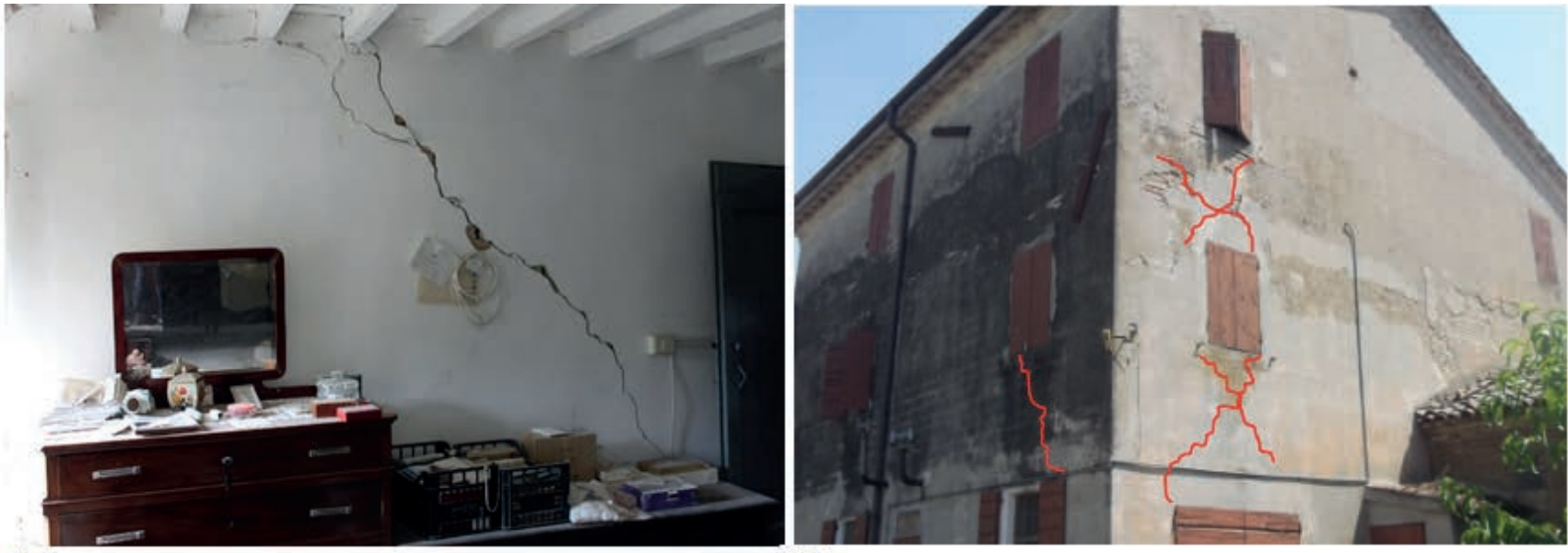

A

B
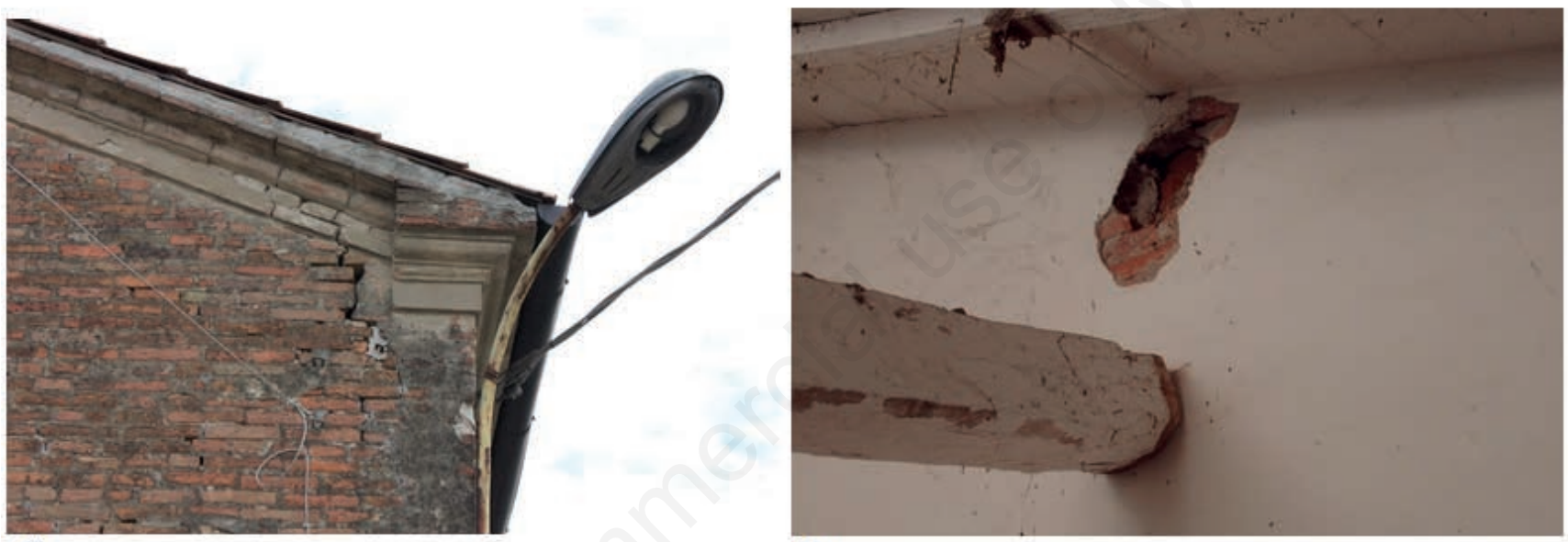

C

D
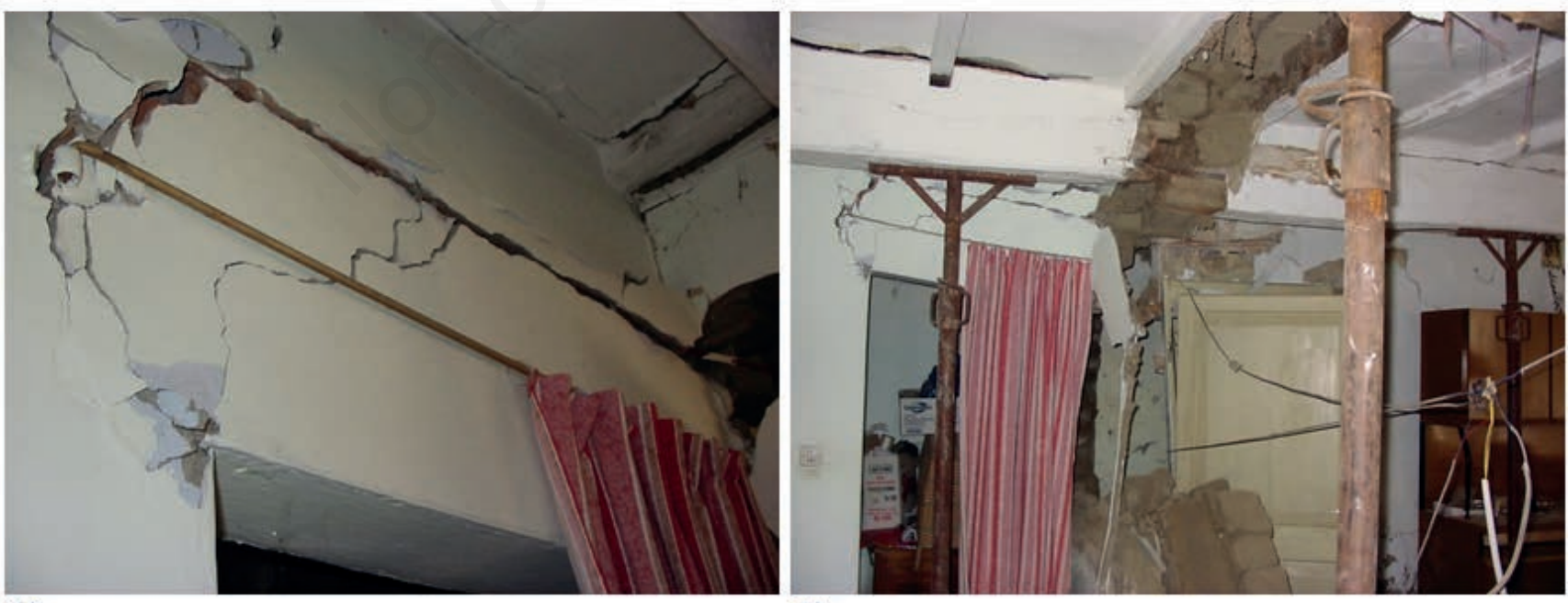

E

Figure 4. Main damages to building category A1. Example of in-plane damages induced by seismic force on: A) partition walls (bldg. \#2); and B) structural walls (bldg. \#6); C) cracking of corner between two orthogonal masonry walls (bldg. \#1); D) loss of support of a wood beams from the masonry panels (bldg. \#2); E) view of a lintel failed; and F) arch collapse (bldg. \#20). 
Due to the high slenderness of vertical walls and columns (the ratio height/thickness could reach values bigger than 20) and because of the distance between the masonry walls, in general the structure is expected to be horizontally very flexible, so large displacements are expected under seismic actions. In fact, the main causes of stable-haylofts collapses can be ascribed to overturning of walls, vertical and horizontal out-of-plane flexure mechanisms. A catastrophic example of collapse for overturning is reported in Figure 5A, involving a whole façade of the buildings from foundation to roof. A similar scenario is showed in Figure 5B, but in this case the out-of-plane flexure collapse anticipated the overturning façade because of the presence of a series of steel ties. Figure 5C shows the global collapse of another historical rural stable-hayloft for horizontal flexure local mechanisms. As the distance from the epicentre region increases, it can be diffusely observed that vertical walls did not collapse, but the buildings reported severe damage to roof elements and in some cases the fall of the main wooden beams. This can probably be attributed to beam-wall relative displacement causing unseating and loss of support of horizontal elements. In fact, due to the building asymmetry introduced for example by non-regular infills, non-symmetric walls (Shariq et al., 2008), presence of portico and stable, two different vertical elements could vibrate in asynchronous way, by imposing at the extremities of horizontal beams, tensile force bigger than friction force and able to activate the sliding mechanism. Figure 5D shows this situation, with pitched-roof collapsed without any apparent damaging to vertical elements.

As already detected during aftermath surveys on historical cultural masonry buildings (Lagomarsino, 2006), the unrestrained forces of the beams of a deformable pitched-roof, excited by the ground motion component in the plane of the beams, can cause the overturning of a limited portion of masonry panels close to the roof. This local damage mechanism, typical of historical churches (Lagomarsino, 2012), has been detected in few cases also for historical stable-hayloft, as depicted for instance in Figure 5E. In some cases (one of them is reported in Figure 5F) the slender columns bearing the hayloft roof reported severe damage conditions at their base (i.e. the roof of the stable), because the horizontal seismic displacements at the building roof imposed a considerable curvature at the base-section where they are clamped.

The principal causes of collapse of this building category must be ascribed to the high slenderness of the vertical walls or columns coupled to the absence of a rigid floor diaphragm able to prevent the relative settlements between different vertical elements and to avoid the sliding of roof beams from their seat. In some cases, the presence of steel ties avoided the overturning of the walls, but these devices were not sufficient to prevent the catastrophic scenario described above.

\section{Damages to building category A3}

The category A3, according to nomenclature adopted in the present paper, collects the barchessa and casella structures, even though a limited number of archetypes are nowadays present in the Emilia territory. In fact, in several cases, the original layout has been modified or enlarged in the years, while in other cases the ancient building has been demolished and replaced with a more modern structure. A couple of historical buildings in the A3 group have been detected during the in-situ surveys. The casella (building \#11 in Table 2) and the barchessa (building \#22) are showed in Figure 6A-D as they appeared a few days after the 29 May earthquake. Similar to some stable-haylofts of category A2, because of large slenderness of vertical walls in absence of a rigid floor diaphragm, in the barchessa building the out-of-plane flexure mechanism of a wall produced the complete collapse of the roof. Instead, in the years, the original casella has been modified since the transverse sides were infilled by masonry walls poorly connected to original corner columns and an intermediate floor has been introduced. Figure 6B shows the most important seismic induced damages to the columns caused by the asymmetric behaviour of the building. Due to the torsion effects, the corner columns were literally cut at the level of the intermediate floor, as proved by the residual settlements highlighted in Figure 6C. Furthermore, the presence of poor column-infill wall connections produced the detachment of the walls during the seismic events (Figure 6D). The structures have been demolished a few months after the earthquake. As already stated in previous section, the authors had information only on two buildings in this category. Due to the reduced samples in the category A3, the damage mechanisms could not completely representative of the whole category. Anyway, Sorrentino et al. (2014) reported in a detailed way the damages they observed during post-earthquake in-field surveys on three caselle (located in the Province of Modena or Province of Reggio-Emilia). By the comparison between the buildings in Sorrentino et al. (2014) and the A3 buildings of the present paper stock, it emerges that main dimensions, materials and construction techniques result very similar and the buildings exhibit same damage/collapse mechanisms. This could represent a first proof of the validity of the outcomes discussed here concerning the collapse mechanisms of building category A3.

\section{Damages to building category A4}

The typical damages to building category A4 are very similar to those observed for residential rural buildings of group A1, due to comparable geometries, but they are magnified because of the poorer materials and construction techniques. In fact, as depicted for example in Figure 6E with regard to warehouse \#14, the collapse of the floor of roof elements is one of the most recurring mechanisms, together with the in-plane failure of walls. Then, in many cases, the overturning of the infill panels not adequately connected to vertical masonry columns was observed. An example is reported in Figure 6F, showing a specific case of masonry infills collapse, where the bricks closing off the original openings have been laid in their own plane creating a panel extremely vulnerable to out-of-plane actions.

\section{Damages to building category $B$}

With reference to composed buildings (labelled as category B in the present paper), it is worth noting that observed damage mechanisms during on-field inspections are very similar to those observed in isolated buildings, and the collapses must probably be ascribed to analogous causes. Moreover, some additional damage sources, to be attributed to the interaction between adjacent bodies, must be considered. In fact, because of their different use, often the interacting bodies had different storey level, inner height and wall slenderness, especially for buildings in group B1-2 mainly damaged by 2012 earthquakes. As a result, in several situations sliding and fallen of roof beams have been observed, as in Figure 7A, where the corner opening between orthogonal walls was not well connected (Figure 7B). Despite their slenderness (if measured on the hayloft side), sometimes the intermediate transverse walls reported X-shape cracks or bricks sliding typical of shear damage mechanism and did not collapse in local way, because of the restraint guaranteed by intermediate storey on the other (i.e. residential) side. With reference to B1-2 category, the most important damages involved the floor/roof diaphragm with elements that, in 

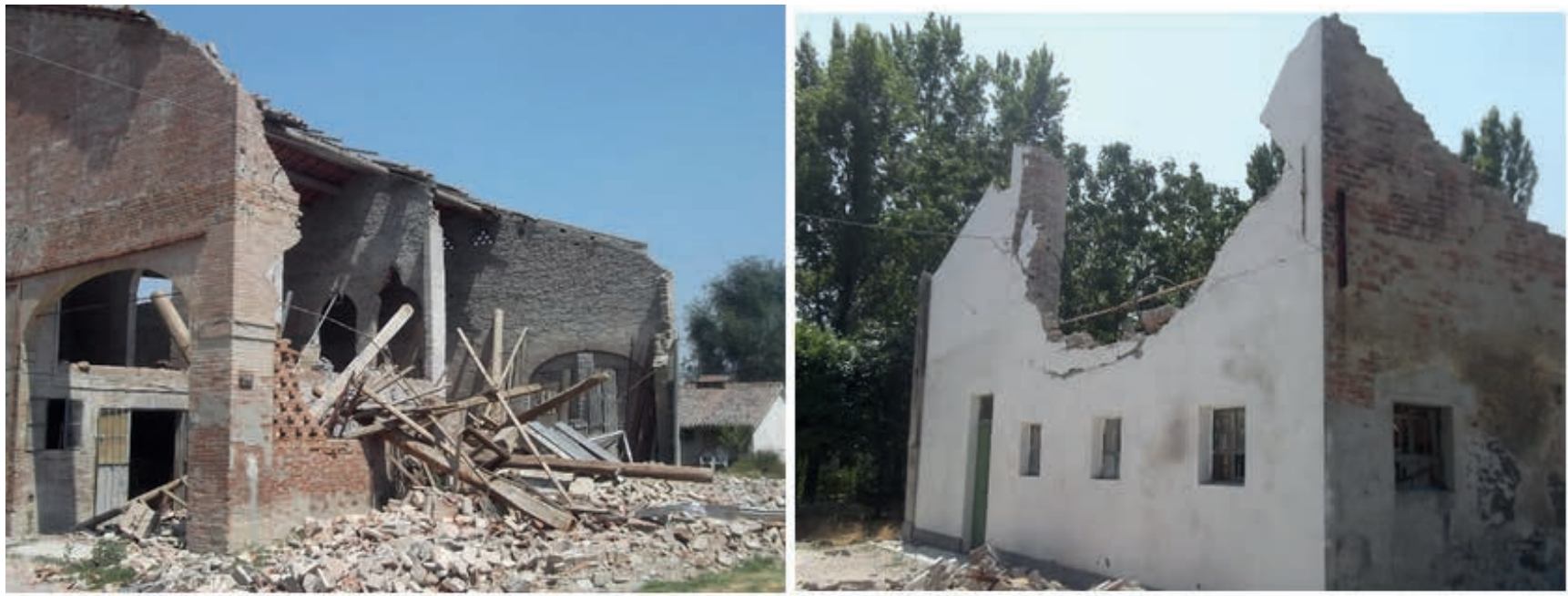

A

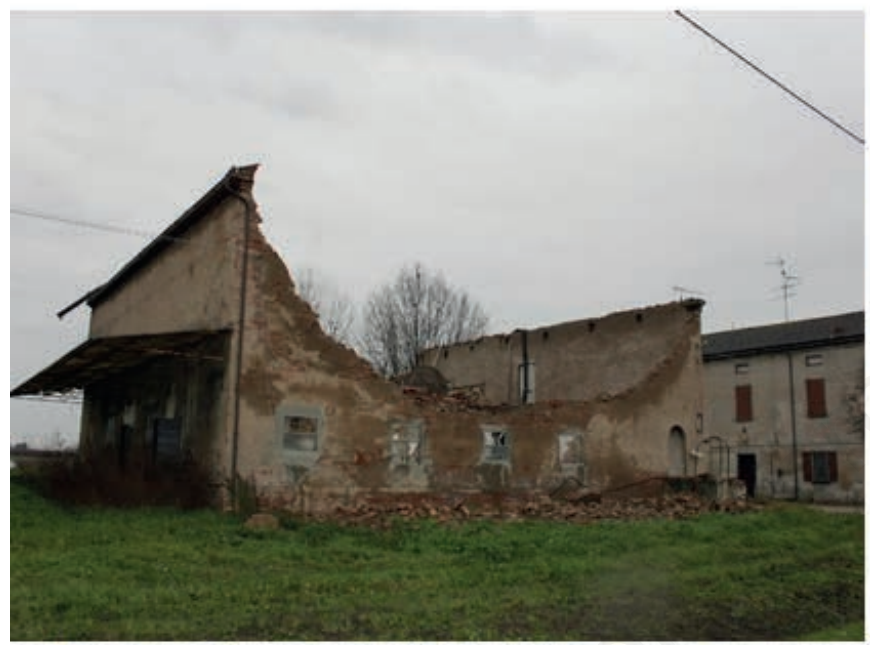

C

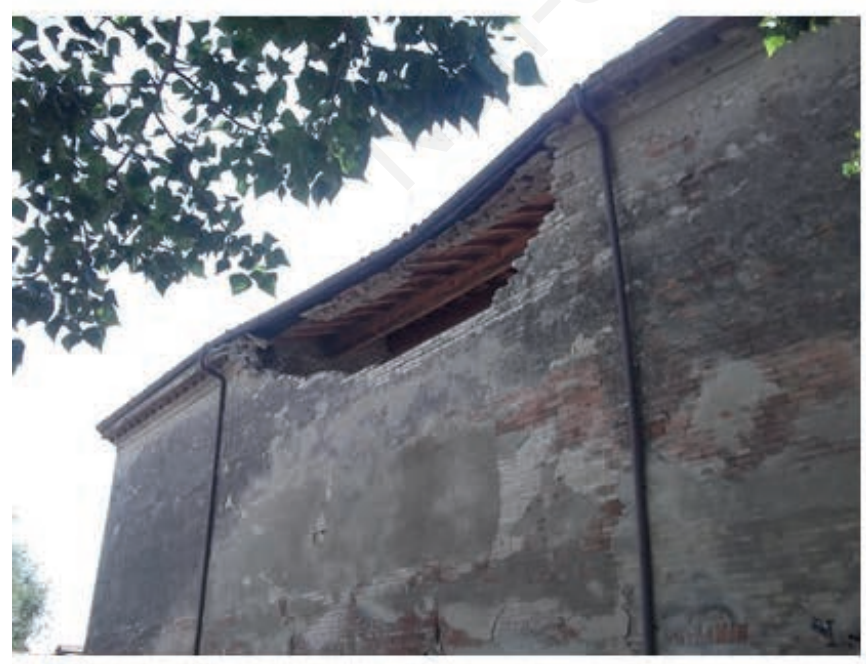

E
B

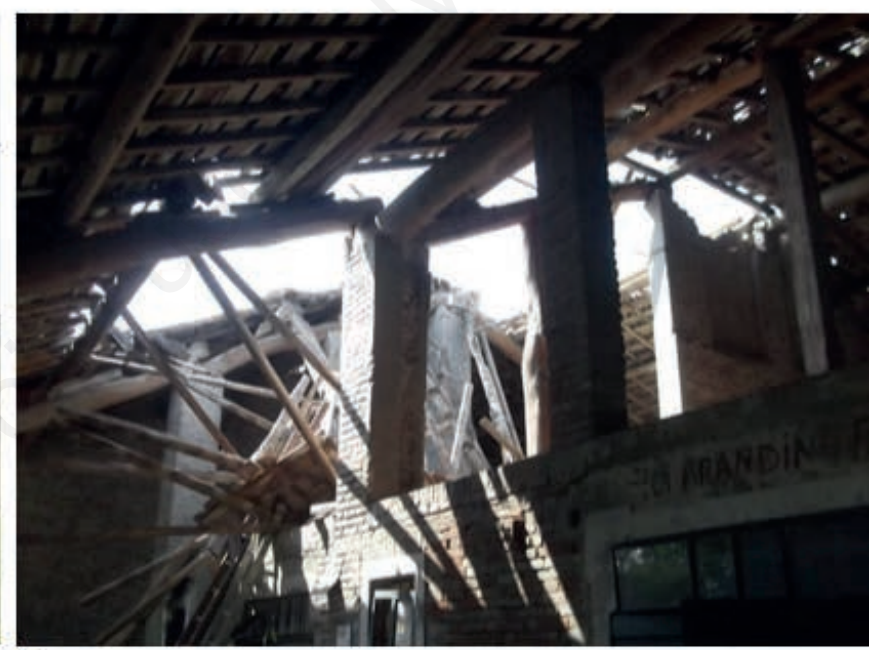

D

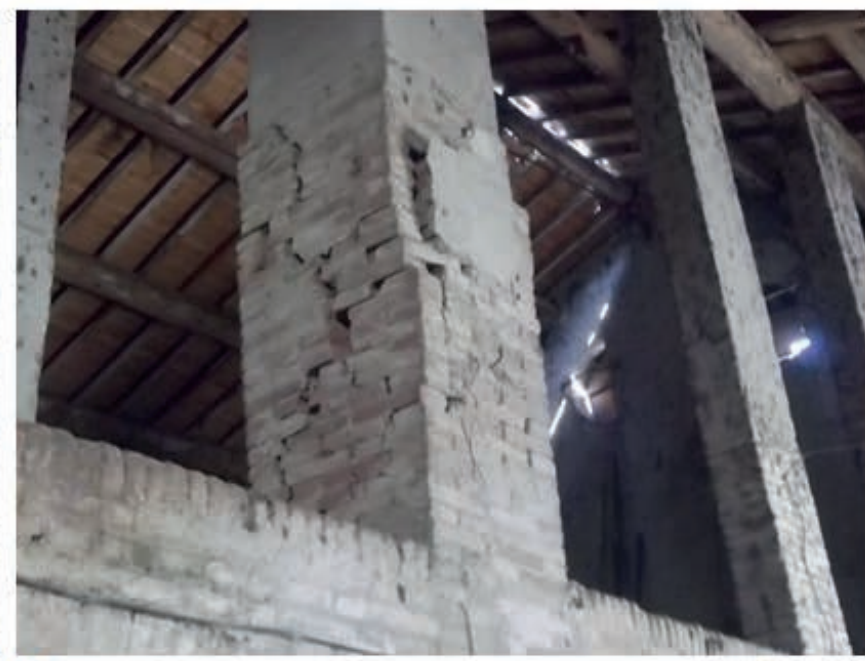

F

Figure 5. Main damages to building group A2. Example of catastrophic stable-hayloft collapses for: A) overturning of the façade (bldg. \#1); B) out-of-plane vertical flexure (bldg. \#18); and C) horizontal flexure mechanism (bldg. \#10). D) Loss of support of the roof beams for the excessive deformations of the building (bldg. \#4). E) Overturning of a limited portion of masonry panels for the horizontal force transmitted by the beam elements of a flexible roof (bldg. \#1). F) Severe damage at the base of a slender masonry column (bldg. \#4). 


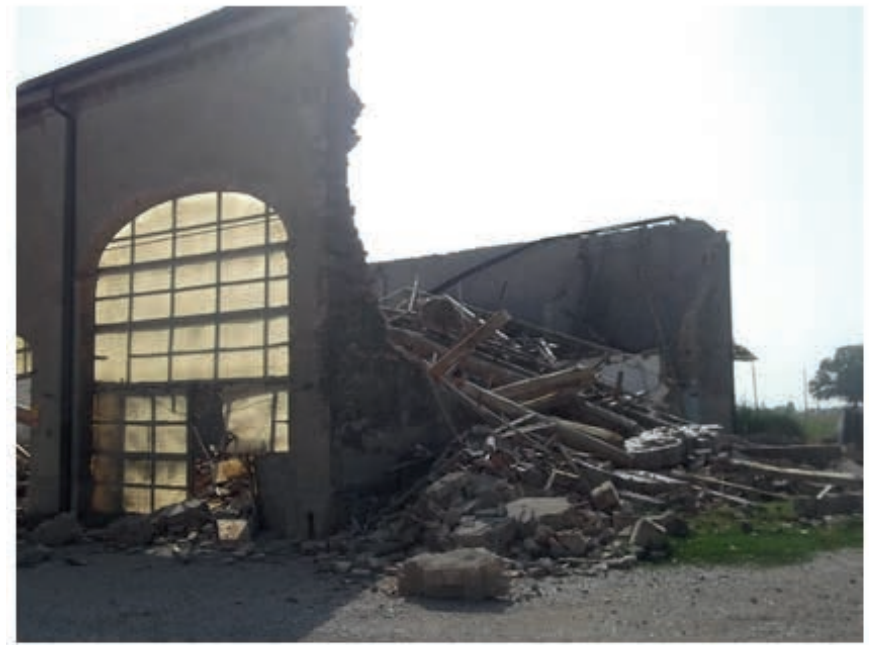

$\mathbf{A}$

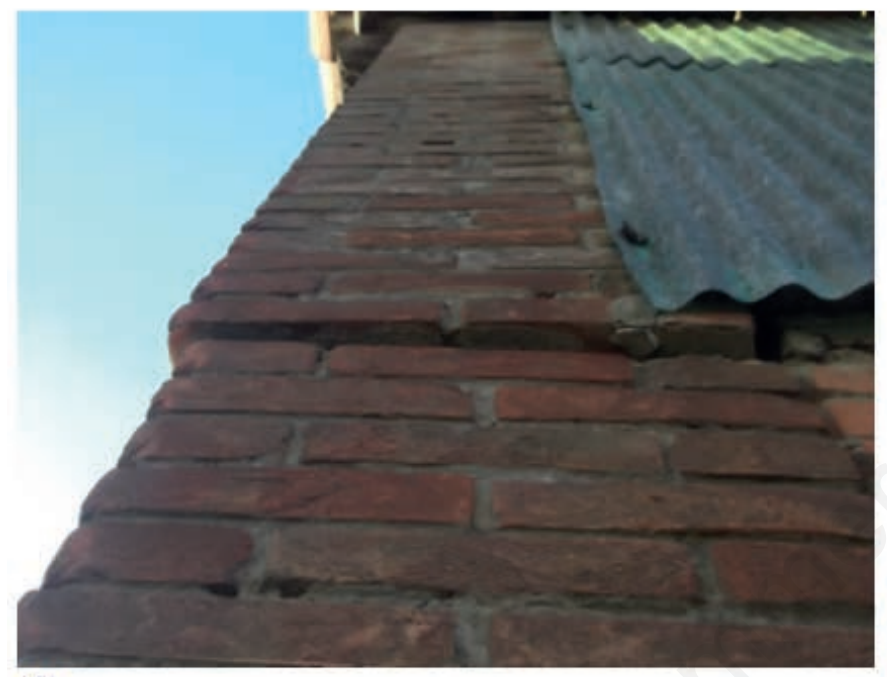

C

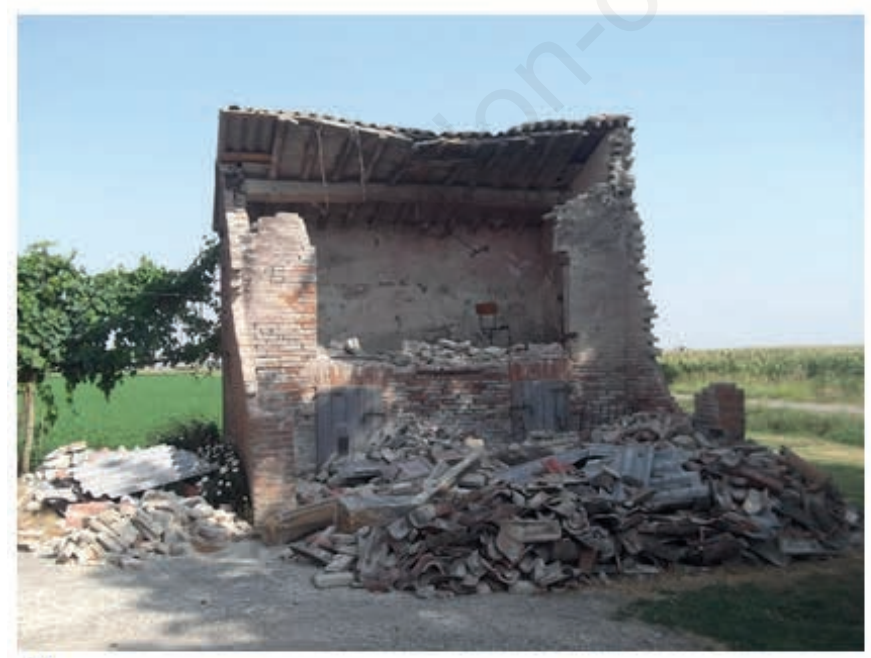

$\mathbf{E}$

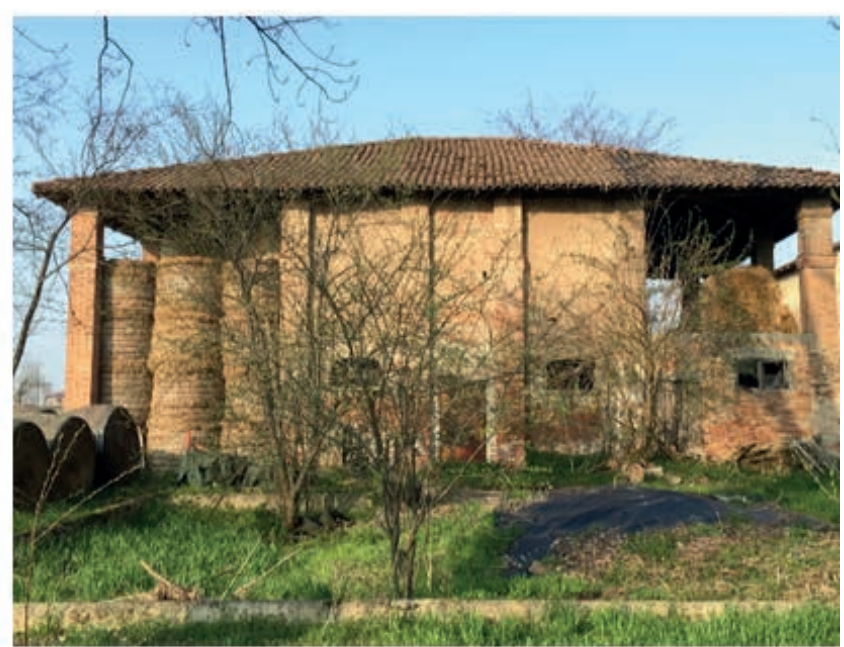

B

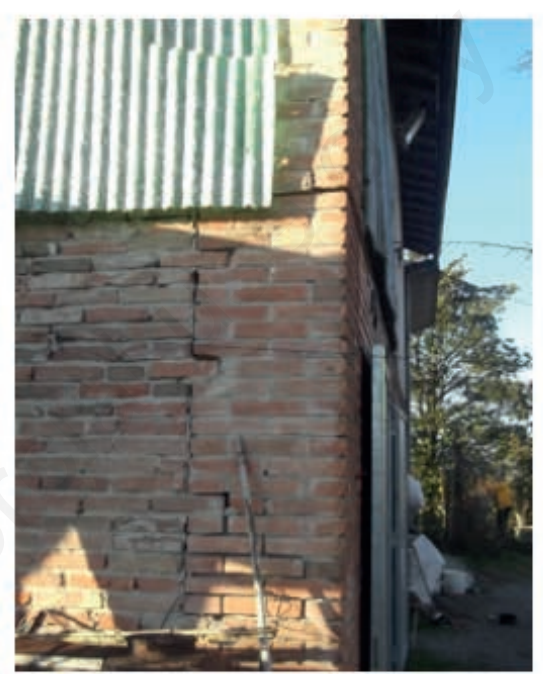

D

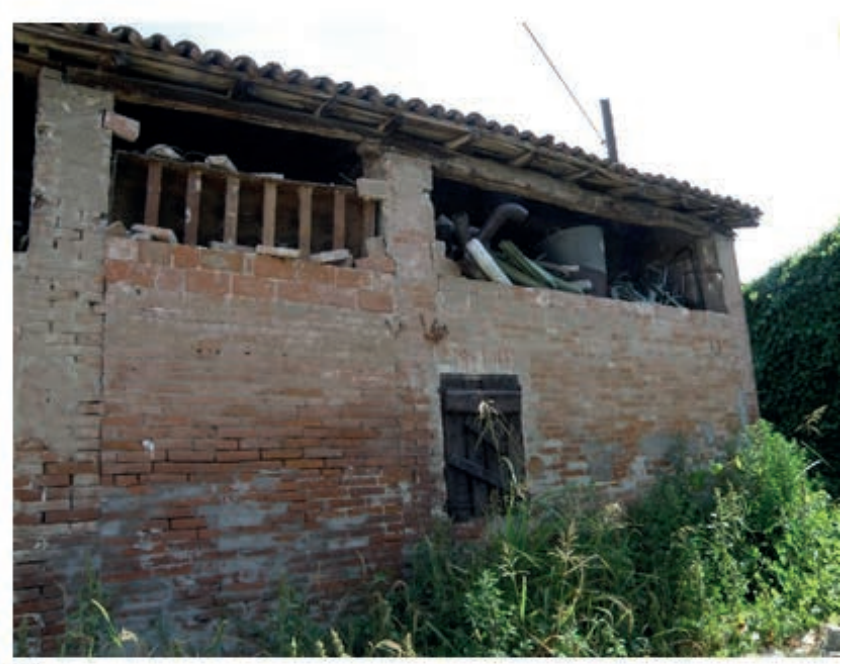

$\mathbf{F}$

Figure 6. Main damages to category A3 and A4. A) Collapse of a barchessa building (bldg. \#22); B) Lateral view of a casella (bldg. \#11) with particulars of severe damages to: $C$ ) masonry columns due to excessive shear force; and D) infill walls for detachment from the structural columns. E) Structure collapse with loss of support of the roof structures (bldg. \#21); and F) overturning of masonry infill walls due to the erroneous arrangement of the bricks (bldg. \#17). 
many cases, slid from their original positions and in some cases fell down. The structures B1-2 results as sensitive to ground motions as the buildings A2, since they have similar maximum walls slenderness values and typically, similar in-elevation discontinuity introduced by hayloft double-volume and in-plane irregularity due to the asymmetrical stable position. Instead, with regard to B1-4 group, collapses were not observed, and only minor damages were detected due to the interaction between adjacent bodies.

\section{Damages to non-structural elements}

Among the most severe seismic damages observed, those affecting non-structural elements have to be highlighted. The fail- ure or fall of these elements do not cause the collapse of the building, however they can represent a serious risk for people inside or close to the building. In Figure $7 \mathrm{C}$ and $\mathrm{d}$ two typical examples are showed. The first is related to the failure of non-structural ornamental elements like the gelosie (Figure 7C), typical holed infill walls widespread in northern Italy. The second refers to perimeter masonry cornice (Figure 7D) typically built with external good texture masonry and internally infilled by waste material and so with poor mechanical strength. These elements often represent the only building friezes, since the vernacular context usually is governed by simplicity. Lastly, as stated upon, in rural buildings it is quite common to find porticos and wooden sheds commonly sup-

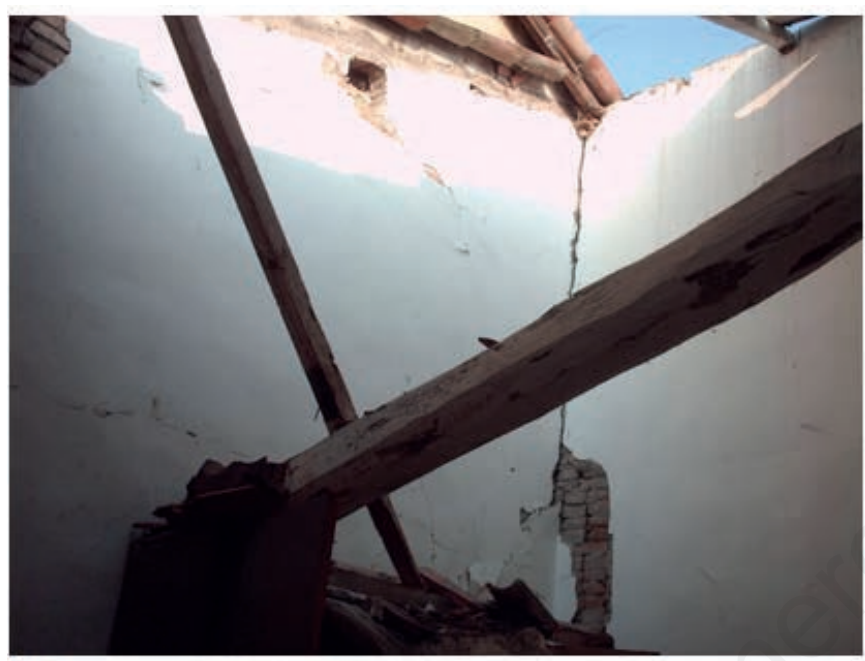

$\mathbf{A}$

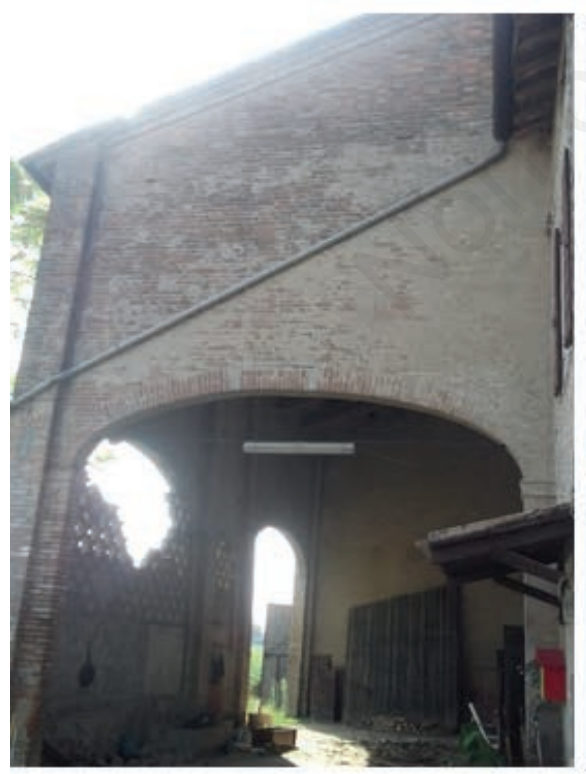

C

Figure 7. Particular of damages to category B buildings and non-structural elements. A) Fallen of timber roof beams from the intermediate wall in a composed building \# 8. B) Corner opening between orthogonal walls poorly connected (bldg. \#8). C) Failure of gelosie, typical holed infill walls (bldg. \#5). D) Fallen of a portion of the perimeter masonry cornice (bldg. \#5). E) Cracking at the base of a masonry column portico (bldg. \#7).

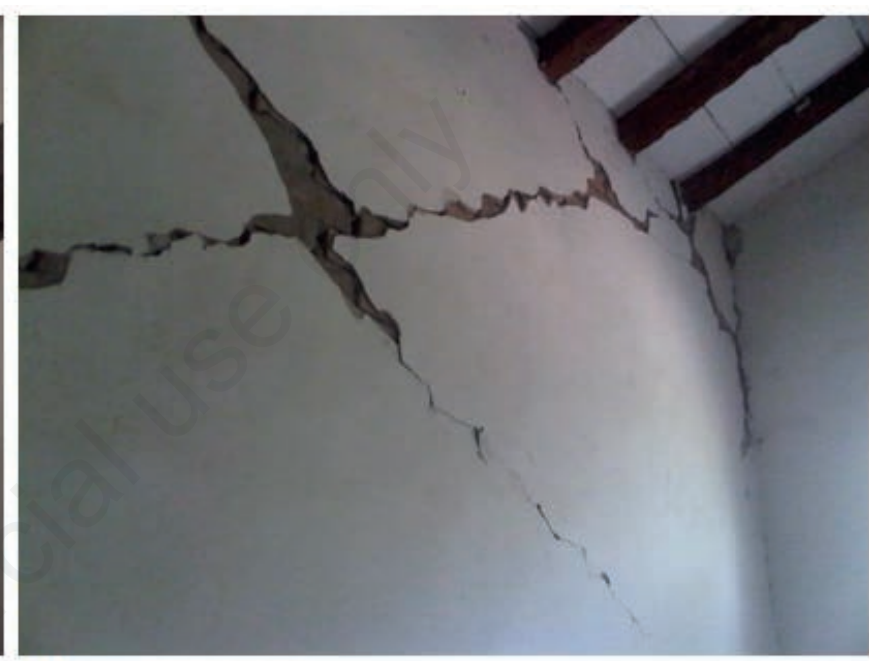

B
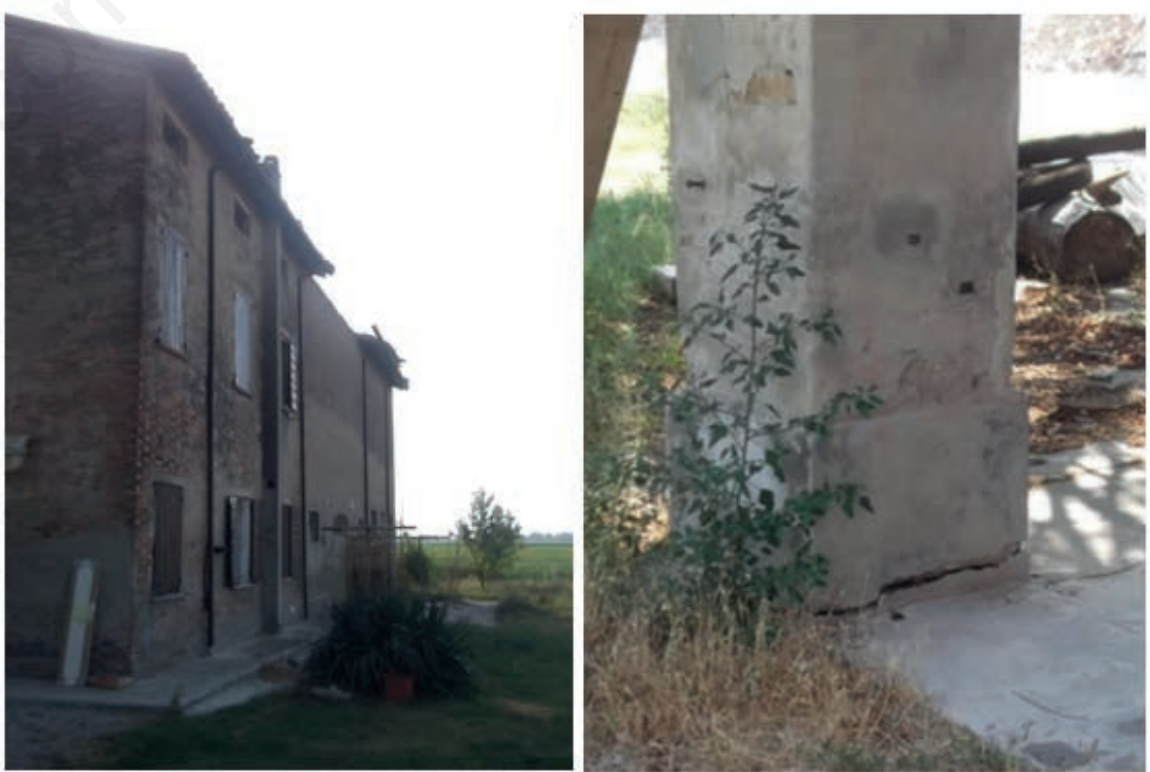

$\mathbf{E}$ 
ported by thin masonry pillars. These columns, during the seismic events, displayed some damages because of their inability to overcome large horizontal displacements. A typical crack pattern of the base portion is showed in Figure 7E. It is evident that the column base-section results partially working because detached by the foundation plinth.

The need to preserve the historical rural heritage of the Emilia territory calls for a suitable design strategy in order to select the most effective technical solutions, compatible with vernacular landscape. Obviously, these solutions are not clearly identifiable if the actual vulnerability are not understood and known. The catastrophic seismic damages and collapses described and detailed in this paper can help to define the best fit strengthening interventions, object of future works, to reduce the sensibility of the historical rural buildings. The main outcomes regarding the damages and collapses on the various category are collected in Table 4 . In the table, the collapse mechanisms have been highlighted in bold so to distinguish from the damage mechanisms. The leading causes producing the collapse (or the worst damages if the collapses are not present, e.g. Category B1-4), were highlighted in bold as well.

From a synthetic analysis emerges that most of the collapses involved the wooden beam elements of floors and roofs. The most widespread wall collapse scenario involved local mechanisms of building categories A2, A3 and B1-2 constituted by slender vertical elements, whereas typically shear or flexure global mechanisms governed the failure of vertical elements of categories A1, A4 and B1-4. In some cases, severe damages occurred to non-structural elements poorly connected to structural systems. By the analyses of the failure scenario, the most important deficiencies have been identified and commented. The recurrent weakness in rural buildings is the presence of very flexible floor/roof diaphragm unable to adequately distribute the seismic forces among the various vertical elements. The poor materials and the scarce construction techniques realising the vernacular buildings represent other important deficiencies to be improved in a suitable way by future strengthening intervention.

\section{Conclusions}

In this paper, the damages and the collapses collected during the surveys on rural historical buildings in the aftermath of the 2012 Emilia earthquakes are presented and commented. It was observed that, in the area hit by the earthquake, a few recurrent typologies are present, and buildings of the same typology showed similar damage mechanisms. Therefore, in order to define the most typical damages affecting the different building typologies, the 22 structures of the building stock under study have been classified in different categories, based on plan distribution and use of the building. The main reason of the collapse of most of the vernacular buildings can be attributed to an incorrect design philosophy, typical of past construction techniques of non-seismic zones, considering only gravitational and wind loads. Moreover, old rural buildings typically represent low quality constructions built with poor construction techniques and materials. The most commonly observed collapses were walls local mechanism (i.e. single or complex overturning, horizontal or vertical flexure) and in some cases in-plane shear of flexure failure. In few cases, the presence of irregular distribution of the infill panels anticipated the failure. The failures can be ascribed to a lack of effective connections between orthogonal walls, poor connections between floor elements and walls, and excessive flexibility of floor diaphragms. In many cases the buildings were demolished because of the severe damages reported. Nowadays, rural buildings are an important cultural heritage, because they represent the architectural, environmental and social distinguishing features of the Emilia landscape and history. However, specific laws or regulations preserving them are nowadays not effective and, in several case, these buildings are currently abandoned and in advanced deterioration state. The outcomes presented in this paper have allowed identifying the building typologies most vulnerable to earthquakes and, from the lesson learned after recent seismic events, to provide information useful to plan the future planning strategies to increase the safety of the historical rural constructions.

\section{References}

Alberti L.B. 1450. De re ædificatoria.

ANTC (Aggiornamento delle Norme Tecniche per le Costruzioni). 2018. Italian Building Code. Ministerial Decree 17/01/2018. [In Italian].

Antrop M. 2005. Why landscapes of the past are important for the future. Landscape Urban Plan. 70:21-34.

Barbaresi A., Dallacasa F., Torreggiani D., Tassinari P. 2017. Retrofit interventions in non-conditioned rooms: calibration of an assessment method on a farm winery. J. Build. Perform. Simul. 10:1.

Barreca F., Modica G., Di Fazio S., Tirella V., Tripodi R., Fichera C.R. 2017. Improving building energy modelling by applying advanced 3D surveying techniques on agri-food facilities. J. Agric. Eng. 48:203-8.

Belleri A., Brunesi E., Nascimbene R., Pagani M., Riva P. 2014. Seismic performance of precast industrial facilities following major earthquakes in the Italian territory. J. Perform. Construct. Facil. 29:04014135.

Bovo M., Savoia M. 2018. Numerical simulation of seismicinduced failure of a precast structure during the Emilia earthquake. J. Perform. Construct. Facil. 32:04017119.

Cattari S., Degli Abbati S., Ferretti D., Lagomarsino S., Ottonelli D., Tralli A. 2013. Damage assessment of fortresses after the 2012 Emilia earthquake (Italy). Bull. Earthq. Eng. 12:2333-65.

Gattesco N., Macorini L. 2014. In-plane stiffening techniques with nail plates or CFRP strips for timber floors in historical masonry buildings. Constr Build Mater. 58:64-76.

Giuriani E., Marini A. 2008. Wooden roof box structure for the anti-seismic strengthening of historic buildings. Int. J. Archit. Heritage 2:226-46.

Hasik V., Chhabra J.P.S., Warn G.P., Bilec M.M. 2018. Review of approaches for integrating loss estimation and life cycle assessment to assess impacts of seismic building damage and repair. Engine. Struct. 175:123-37.

Lagomarsino S. 2006. On the vulnerability assessment of monumental buildings. Bull. Earthquake Eng. 4:445-63.

Lagomarsino S. 2012. Damage assessment of churches after L'Aquila earthquake (2009). Bull. Earthquake Eng. 10:73-92.

Ortolani M. 1953. La casa rurale nella pianura emiliana. Centro di Studi per la Geografia Etnologica, Florence, Italy.

Özmen C., Ünay A.I. 2007. Commonly encountered seismic design faults due to the architectural design of residential buildings in Turkey. Build. Environ. 24:1406-16.

Parisi F., Augenti N. 2013. Earthquake damages to cultural heritage constructions and simplified assessment of artworks. Engine. Fail. Analysis 34:735-60. 
Penna A., Morandi P., Rota M., Manzini C.F., da Porto F., Magenes G. 2013. Performance of masonry buildings during the Emilia 2012 earthquake. Bull. Earthq. Eng. 12:2255-73.

Piazza M., Baldessari C., Tomasi R. 2008. The role of in-plane floor stiffness in the seismic behaviour of traditional buildings. $14^{\text {th }}$ World Conf. Earthq. Eng., Beijing, China.

Picuno P. 2012. Vernacular farm buildings in landscape planning: a typological analysis in a southern Italian region. J. Agricult. Engine. XLIII:130-7.

Scotta R., Trutalli D., Marchi L., Pozza L. 2018. Seismic performance of URM buildings with in-plane non-stiffened and stiffened timber floors. Eng. Struct. 167:683-94.

Secchi P. 1999. Proceedings of alerts and lessons learned: an effec- tive way to prevent failures and problems (Technical Report WPP-167). ESTECS, Noordwijk, The Netherlands.

Shariq M., Abbas H., Irtaza H., Qamaruddin M. 2008. Influence of openings on seismic performance of masonry building walls. Build. Environ. 43:1232-40.

Sorrentino L., Liberatore L., Liberatore D., Masiani R. 2014. The behaviour of vernacular buildings in the 2012 Emilia earthquakes. Bull. Earthquake Eng. 12:2367-82.

Toker S., Ünay A.I., 2006. Re-characterisation of architectural style of reinforced concrete building facades by exterior seismic strengthening. Build. Environ. 41:1952-60.

Tomazevic M. 2000. Earthquake - resistant design of masonry buildings. Imperial College Press, London, UK. 